\title{
Prevalence of Neonatal Cryptosporidiosis in Andean Alpacas (Vicugna pacos) in Peru
}

\author{
M.T. López-Urbina ${ }^{1}$, A.E. González ${ }^{*}{ }^{1}$, L.A. Gomez-Puerta ${ }^{1}$, M.A. Romero-Arbizu ${ }^{1}$, \\ R.A. Perales-Camacho ${ }^{1}$, F.A. Rojo-Vázquez ${ }^{2}$, L. Xiao ${ }^{3}$ and V. Cama ${ }^{3}$ \\ ${ }^{I}$ Departamento de Salud Animal/Salud Pública, Facultad de Medicina Veterinaria, Universidad Nacional Mayor de San \\ Marcos, Lima, Perú \\ ${ }^{2}$ Departamento de Patología Animal/Sanidad Animal, Facultad de Veterinaria, Universidad de León, España \\ ${ }^{3}$ Centers of Disease Control and Prevention, Atlanta, GA, USA
}

\begin{abstract}
A national survey was conducted to evaluate the prevalence of Cryptosporidium $s p$. in alpacas 1 to 15 days-old of age (crias) in 105 Andean herds. Stool samples of 5,163 randomly selected crias from 7 representative geographical regions of Peru were screened using acid fast staining microscopy. Ninety percent of $\sim 2.9$ million Peruvian alpacas are raised in these areas. Data on geographical characteristics and husbandry practices by region were also collected. Prevalence was determined by study areas and by age (five categories set at three-day intervals). Cryptosporidium sp. was detected in crias from all 7 regions. The overall prevalence was $13 \%$, ranging from 7 to $23 \%$ per region. Prevalence was $2 \%$ in the youngest and showed an increasing trend by age, reaching $20 \%$ in crias $12-15$ days old. These oldest crias were more likely to have cryptosporidiosis $(\mathrm{OR}=2.2, \mathrm{p}<0.01)$. Infections with Cryptosporidium were also significantly associated with low availability of grazing grounds and overcrowding at birth $(\mathrm{p}<0.01)$. This study demonstrates that Cryptosporidium is a frequent pathogen in Andean alpaca crias, and suggest that cryptosporidiosis may play a significant role in the alpaca neonatal diarrhea complex that causes significant morbidity and mortality among crias.
\end{abstract}

Keywords: Cryptosporidium, Cryptosporidiosis, Alpacas, Neonatal diarrhea.

\section{INTRODUCTION}

Alpacas (Vicugna pacos) are important for the economy of Peruvian peasants who live at $\geq 3,500 \mathrm{~m}$ above sea level (MASL) [1]. More than $70 \%$ of the world's alpaca population is in the Andean "Altiplano", located at 3,500 to 4,100 MASL. The Altiplano is characterized by cold weather, limited rainfall, oxygen deficient environment (thin air) and large plateaus, with interspread mountains and valleys. Grazing areas are predominantly composed of native pastures rich in fiber and deficient in protein and key nutrients. Nonetheless, alpaca husbandry is a vital economic activity because it is the only potentially profitable farming alternative in these challenging conditions [2].

Cryptosporidium sp. is a ubiquitous and significant enteropathogen of both immunocompetent and immunocompromised vertebrate hosts [3, 4], and Cryptosporidium parvum has been identified as an important agent of the ruminant neonatal diarrhea syndrome [2, 5-10]. Cryptosporidium spp. are highly prevalent among several ruminant species [11], causing severe enteric disease, and economic loses [12, 13]. Cryptosporidium spp. have been described in young alpacas from 3 to 15 days of age $[14,15]$, and therapies or vaccines are not available to prevent or control this parasite in animals [16].

*Address correspondence to this author at the Departamento de Salud Animal/Salud Pública, Facultad de Medicina Veterinaria, Universidad Nacional Mayor de San Marcos, Lima, Perú, Av. Circunvalación Cdra. 28 s/n San Borja. Lima - Perú; Tel: +11-511-436-8938; Fax: +511-436-1027; E-mail: agonzale@jhsph.edu
Neonatal alpacas (crias) are susceptible to enteritis and the neonatal diarrhea syndrome (NDS). This syndrome is characterized by self-limiting watering diarrhea lasting for up to15 days, refractory to antibiotic treatments and, that is neither bacterial nor viral in origin $[17,18]$. NDS is the most common and costly enteric disease affecting newborn llamas and alpacas [1, 19-21].

Cryptosporidium was first described as a fortuitous and innocuous parasite in alpaca crias, and its relationship with neonatal enteritis or diarrhea was not addressed [22]. Recently, however, C. parvum has been reported in diarrheic stools of young alpacas raised in small farms in the U.S.A. and England [23-26]. An experimental infection study using Cryptosporidium oocysts isolated from diarrheic stools from alpacas crias reproduced symptoms and course of the newborn alpaca atypical diarrhea reported by Moro in 1965 [18], this suggests that Cryptosporidium may be one of the etiologies of the alpaca NDS [27]. However, the prevalence of this parasite in alpaca crias raised under native husbandry practices in the Altiplano remained undetermined. According to the last national survey in Peru about 2'900,900 alpacas grazed in the Altiplano, at between 3,800 and 5,000 MASL [28]. Four regions of Peru have about $90 \%$ of the national population of alpacas: Puno ( $\sim 1.7$ million), Cuzco $(\sim 340,000)$ Huancavelica $(\sim 330,00), \quad$ and Arequipa $(\sim 230,000$ alpacas).

Here we describe the first major epidemiologic survey of Cryptosporidium in alpaca crias $<15$ days-old in the Peru- 
Table 1. Altitude and Husbandry Characteristics by Regions, 1996

\begin{tabular}{|c|c|c|c|c|}
\hline $\begin{array}{c}\text { Geographical Region } \\
\text { (Department) }\end{array}$ & $\begin{array}{c}\text { Altitude (Meters Above } \\
\text { Sea Level) }\end{array}$ & $\begin{array}{c}\text { Availability of Grazing } \\
\text { Grounds }\end{array}$ & $\begin{array}{c}\text { Good Management } \\
\text { Practices }\end{array}$ & No \\
\hline \hline Arequipa & $3,800-4,000$ & High Birth & No \\
\hline Ayacucho & $4,200-5,300$ & High & Yes & No \\
\hline Cuzco & $3,800-4,400$ & High & No & No \\
\hline Huancavelica & 4,500 & Low & Yes \\
\hline Junín & $4,100-4,600$ & High & Yes & Yes \\
\hline Pasco & 4,600 & High & Yes & Yes \\
\hline Puno & $4,000-4,350$ & Low & & \\
\hline
\end{tabular}

vian Andes, the natural habitat for almost $80 \%$ of the world population of alpacas.

\section{MATERIALS AND METHODOLOGY}

\section{Study Sites}

The survey was conducted in 7 regions that have more than $90 \%$ of the alpaca population in Peru. Data on management practices, spacing in calving areas and the availability of grazing grounds were collected from each region. Good management practices were defined as use of iodine disinfection of the umbilical cord at birth, colostrum intake shortly after birth, availability and use of weather shelters, having a pasture rotation plan, and use of animal identification methods. Overcrowding at birth was defined as less than 2 meters of distance between alpaca mothers in the calving areas. The availability of grazing grounds was considered high if there were four or fewer alpacas/hectare.

In 1995 we conducted a preliminary study in 6 herds of alpacas in the region of Cuzco. Data from that survey was used to optimize procedures of this study and calculate the sample size for the national survey. Stool samples from 241 alpaca crias ( $<15$ days-old) were collected; 24 crias had Cryptosporidium in their stools, with a resulting prevalence of $10 \%$ (Table 2 ). This preliminary study also showed variation among herds $(0-30 \%)$, finding that was also used to design the national survey and evaluate potential predictors of infection.

Table 2. Prevalence of Cryptosporidium in Alpaca Crias: Preliminary Study in Cuzco 1995

\begin{tabular}{|c|c|}
\hline Herd & Prevalence (\%) \\
\hline \hline P1 & $1 / 69(1)$ \\
\hline P2 & $2 / 63(3)$ \\
\hline P3 & $18 / 61(30)$ \\
\hline P4 & $0 / 17(0)$ \\
\hline P5 & $2 / 24(8)$ \\
\hline P6 & $1 / 7(14)$ \\
\hline TOTAL & $\mathbf{2 4 / 2 4 1 ( 1 0 )}$ \\
\hline
\end{tabular}

\section{Study Animals}

Alpaca crias up to 15 days of age were randomly selected from 105 herds in 7 regions of Peru (Fig. 1), and they were not selected by breeds or sex. Age was the only selection parameter. This age was based on findings from the preliminary study, and reports from neonatal lambs [29-31], calves [32], and case reports from alpacas [33-37].

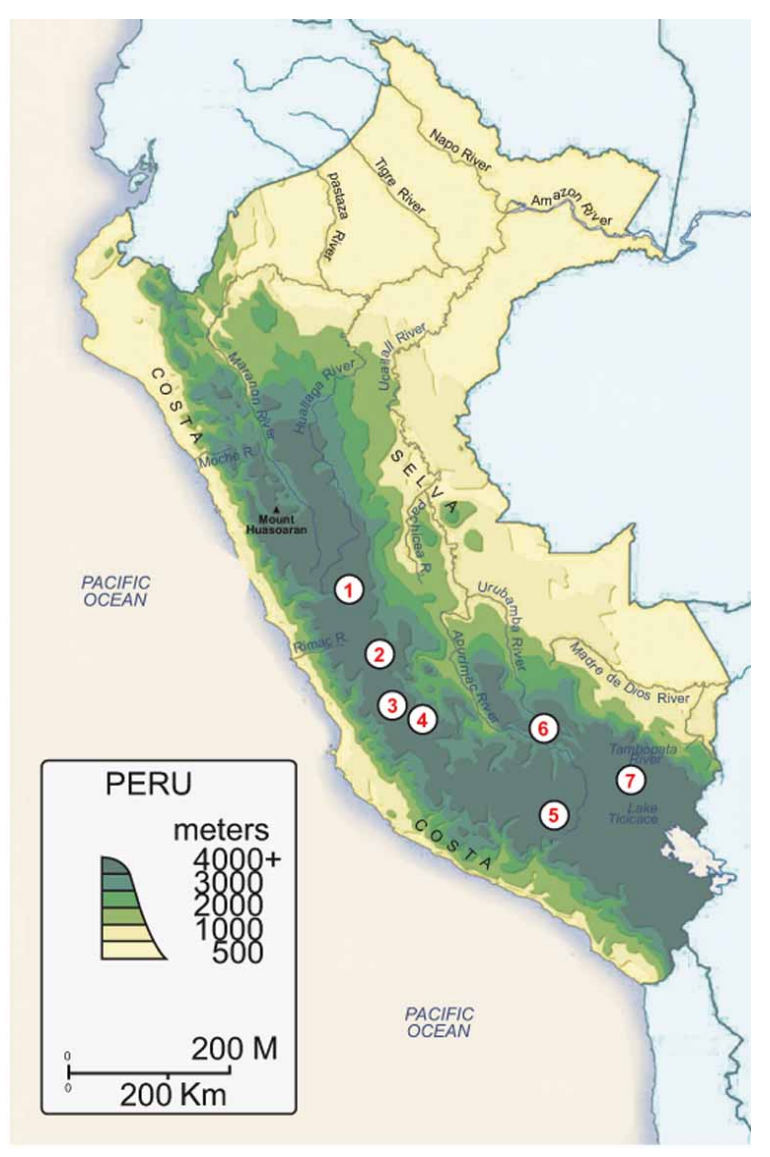

Fig. (1). Physical map of Peru and location of the regions surveyed. 1 - Pasco, 2 - Junin, 3 - Huancavelica, 4 - Ayacucho, 5 - Arequipa, 6 - Cuzco, 7 - Puno. 
Table 3. Prevalence of Cryptosporidium in Fecal Samples of 5,163 Alpaca Crias from 105 Herds in 7 Regions of the Peruvian Andes

\begin{tabular}{|c|c|c|}
\hline Region (Number of Herds Surveyed) & Prevalence (\%) & Confidence Limits \\
\hline \hline Ayacucho (13) & $46 / 672(7)$ & $6.9-8.8$ \\
\hline Cuzco (8) & $62 / 686(9)$ & $7.9-11.2$ \\
\hline Arequipa (37) & $86 / 940(9)$ & $7.8-13.1$ \\
\hline Pasco (16) & $55 / 526(10)$ & $10.1-14.1$ \\
\hline Junín (7) & $125 / 1,030(12)$ & $18.7-25.1$ \\
\hline Huancavelica (18) & $140 / 639(22)$ & $19.5-25.9$ \\
\hline Puno (6) & $152 / 670(23)$ & $\mathbf{1 2 . 0 - 1 3 . 8}$ \\
\hline TOTAL & $\mathbf{6 6 6 / 5 , 1 6 3 ( 1 3 )}$ & \\
\hline
\end{tabular}

\section{Sample and Data Collection}

Stool samples were collected directly from the rectum of each alpaca and placed into labeled new polyethylene bags. Data collected included date, age, sex and location of each animal. The geographical characteristics and husbandry practices were also recorded for each site.

The samples were directly transported to the local laboratory, and processed for microscopy examination. Briefly, direct smears covering the surface of a glass slide were made using about $50 \mu \mathrm{l}$ of stools, fixed in methanol, and stained using the Ziehl-Neelsen modified acid fast stain [38]. The whole smear on each slide was microscopically analyzed at 400x magnification.

\section{Bio-Statistical Analyses}

The sample size for the preliminary study was determined at 214 using the formula $\mathrm{N}=\left(\mathrm{z}^{2} \mathrm{pq}, / \mathrm{E}^{2}\right)$, where $\mathrm{p}=0.167$ was from previously reported prevalence (Rojas 1988), $z=1.96$ for the $95 \%$ confidence interval, and $E=0.05$ was the significance level. The prevalence value from the preliminary study $(10 \%)$ was used to calculate the sample size for the national survey: $\geq 130$ crias per region. Due to the previously observer high variation in prevalence among herds, the sample size was arbitrarily increased to $\sim 600$ crias per region.

Data were organized into 5 age categories set at 3 dayincrements, from day 1 to 15 , and analyzed using the EpiInfo software (http://www.cdc.gov/epiinfo/, Centers for Disease Control and Prevention, Atlanta, GA). The total prevalence rates were determined using frequency tables, determining
95\% confidence limits as previously described [39, 40]. Risk factors such as husbandry practices, density at calving and availability of grazing areas were evaluated for its association with cryptosporidiosis using Chi-square analysis, with $\mathrm{p}<0.05$ as the significance level.

\section{RESULTS}

A total of 5,163 stool samples were analyzed for the presence of Cryptosporidium spp. and 666 crias had Cryptosporidium in their stools, with an overall prevalence of $13 \%$ (Table 3). The prevalence rates varied among herds and were proportional to the alpaca population in each region, ranging from 7 to $23 \%$ (Table 3). Chi-Square analyses showed significant associations between the detection of Cryptosporidium and low availability of grazing grounds (Chi Square, OR-1.37, $\mathrm{p}<0.01)$. The highest prevalence rates $(23$ and $22 \%$ ) were observed in Puno and Huancavelica, respectively, and both regions had low availability of grazing grounds (Tables 1 and 3). In contrast, the lowest prevalence was observed in Ayacucho (7\%) a region with high availability of grazing grounds (Tables $\mathbf{1}$ and $\mathbf{3}$ ). The availability of grazing grounds was significantly associated with lower rates of cryptosporidiosis (Chi-square analysis, $\mathrm{OR}=0.37$, confidence interval 0.33-0.44, $\mathrm{p}<0.001)$.

The prevalence of Cryptosporidium also varied by age groups, showing an incremental trend by age with significant higher prevalence $(p<0.001)$ in older crias (Table 4). Newborns (1-3 days old) had 2\% prevalence, and this rate increased with age, reaching up to $20 \%$ in crias $13-15$ days of age. The older crias were 2.2 times more likely to have Cryptosporidium (Chi-square analysis, $\mathrm{OR}=2.27$, confidence in-

Table 4. Prevalence of Cryptosporidium spp. in Crias by Age Categories

\begin{tabular}{|c|c|c|}
\hline Age (days) & Prevalence (\%) & 95\% Confidence Limits \\
\hline \hline $1-3$ & $17 / 704(2)$ & $1.84-2.99$ \\
\hline $4-6$ & $95 / 1,087(9)$ & $1.88-9.6$ \\
\hline $7-9$ & $110 / 944(12)$ & $14.36-16.59$ \\
\hline $10-12$ & $163 / 1,053(15)$ & 12.7 \\
\hline $13-15$ & $281 / 1,375(20)$ & 19.3521 .52 \\
\hline
\end{tabular}


terval 1.91-2.78, $\mathrm{p}<0.001)$ than alpacas 12 days old or younger.

\section{DISCUSSION}

This study evaluated the presence of Cryptosporidium in 5,163 alpaca crias showing a total prevalence of $13 \%$ (Table 3). Cryptosporidium was prevalent in all regions studied, which were representative of the natural habitat of alpacas in the Andes. Results from the 1995 survey in Cuzco (baseline data), and this national survey, showed that the prevalence rates were relatively similar in both years (10 and $13 \%$ respectively, Tables $\mathbf{2}$ and $\mathbf{3}$ ) suggesting that Cryptosporidium is indeed endemic among alpaca crias.

The endemnicity of Cryptosporidium varied significantly among regions. The highest prevalence rates were found in Huancavelica and Puno, both regions with low availability of grazing grounds, a risk factor significantly associated with criptosporidiosis in the present study. In contrast the region of Ayacucho presented the lowest prevalence and higher availability of grazing grounds. Junín also had a relatively low prevalence of cryptosporidiosis $(12 \%)$ in the 7 herds evaluated but it also had higher availability of grazing grounds and good management practices, which were reported to decrease the incidence of cryptosporidiosis in other ruminants [41-43].

In Puno, alpacas are usually kept in large herds that are managed by community-owned enterprises, resulting in a higher density of alpacas and less efficient or individual control of crias [44]. Huancavelica was another region with very high infection rates $(22 \%)$. In contrast to Puno, most alpacas belonged to small size companies, thus were raised at lower animal densities. However, the accessibility to pastures was as limited as in Puno. Thus, the limited availability of grazing areas in both regions seems to be a likely predictor of Cryptosporidium in alpaca crias. The harsh weather and ecological features of the Altiplano preclude the widespread establishment of improved pastures, thus, grazing areas are more a geographical feature than a farming practice. Therefore, the availability of grazing grounds could be indirect indicators of animal crowding, lower nutrient consumption, concentration of parasites in hot spots, or combinations thereof. Thus, further studies would be needed to elucidate the role of avaibility of grazing grounds, overcrowding at birth and other potential risk factors.

The prevalence rates in alpaca crias ranged from 7 to $23 \%$, and may be lower than previously reported in other ruminant species. In calves for example, the prevalence of $C$. parvum in France among 1628 selected calves was $17.9 \%$, although the rates of diarrhea were only $5.3 \%$. Another study conducted in 1996 reported Cryptosporidium in 55.6\% of 189 livestock farms on samples from calves ages 4 to 21 day. Among the 440 calves examined, of which 398 (90.5\%) presented diarrhea, cryptosporidia were found in 191 animals, i.e. a prevalence of $43.4 \%$ (C.I. $95 \%=[38.8-48.0 \%]$ ) [7]. These data, however are from farms in industrialized nations where dairy or beef cattle are raised using highly efficient practices that include high density production for dairy animals and defined pastures for beef cattle.

The alpacas in our survey, however, were usually raised in herds that roamed independently or semi-independently from each other for 10-11 months each year. However, once a year all herds converge on defined sites for a few weeks for several key activities: delivery of newborns, mating of breeders, shearing of selected adults, and deworming of the herds. Thus, despite the differences in husbandry practices and wide geographical setting, Cryptosporidium was still detected in $\sim 13 \%$ of the alpaca crias.

Several husbandry practices have been reported to influence the prevalence of cryptosporidiosis, such as herd size, sanitation practices and geographic location $[8,44]$. For example, in Ayacucho, the department with the lowest prevalence, farmers emphasize the consumption of colostrum by crias, while they have also implemented a rotation scheme of sleeping sites. These practices may have influenced the relatively low rates $(7 \%)$ of Cryptosporidium in this region. Other husbandry practices for newborns, such as adequate rotation of calving areas has been reported to prevent cryptosporidiosis [44-47], however this is not frequent among alpaca farmers and may be considered in future studies.

How do alpacas acquire Cryptosporidium, or its role in the alpaca NDS remains unknown. As with other ruminants, the sources of infection could be other infected animals of the same species or others, such as cattle, rodents or even wildlife. However, the recent finding that $C$. parvum is primarily found among very young cattle suggests that transmission of Cryptosporidium could occur primarily between alpaca crias. Nevertheless, the species or genotypes of Cryptosporidium infecting alpacas, and the role of other alpacas, including mothers, either as reservoirs or asymptomatic carriers would need to be elucidated in future studies.

\section{CONCLUSION}

The present study shows that alpaca crias can have Cryptosporidium spp. shortly after birth. The prevalence of this parasite was associated with low availability of pastures and can also be influenced by management practices in the calving areas. Because cryptosporidiosis occurs in young crias, this parasite may also play a significant role in the alpaca neonatal diarrhea syndrome. A case control study should be necessary to clearly elucidate the role of Cryptosporidium in this syndrome.

\section{ACKNOWLEDGEMENTS}

This study was supported in part by the Ministerio de Educación y Ciencia de España. We are indebted to Dr. Reyes (SENASA-Huancavelica) Dr. Gamarra (SAIS Tupac Amaru, Junín), Dr. José Alva (FMV-UNMSM, Lima), Dr. Feliciana Vilca (Puno), authorities of Centro Experimental de Camélidos La Raya, (Puno), and the agricultural communities of Puno, Junín, Cerro de Pasco, Cuzco, Arequipa, Ayacucho and Huancavelica for their help and support for this study. We are thankful to Dr. Walter Braga for comments and review of this manuscript.

The findings and conclusions in this report are those of the authors and do not necessarily represent the views of the Centers for Disease Control and Prevention.

\section{REFERENCES}

[1] Bradford GE, Burfening PJ, Cartwright TC. Evaluation of production and reproduction of sheep, goat and alpaca genotypes in the 
Small Ruminant Collaborative Research Support Program. J Anim Sci 1989; 67(11): 3058-67.

[2] Leguia G. The epidemiology and economic impact of llama parasites. Parasitol Today 1991; 7(2): 54-6.

[3] Xiao L, Morgan UM, Fayer R, Thompson RC, Lal AA. Cryptosporidium systematics and implications for public health. Parasitol Today 2000; 16(7): 287-92.

[4] Xiao L, Ryan UM. Cryptosporidiosis: an update in molecular epidemiology. Curr Opin Infect Dis 2004; 17(5): 483-90.

[5] Holland RE. Some infectious causes of diarrhea in young farm animals. Clin Microbiol Rev 1990; 3(4): 345-75.

[6] Huetink RE, van der Giessen JW, Noordhuizen JP, Ploeger HW. Epidemiology of Cryptosporidium spp. and Giardia duodenalis on a dairy farm. Vet Parasitol 2001; 102(1-2): 53-67.

[7] Lefay D, Naciri M, Poirier P, Chermette R. Prevalence of Cryptosporidium infection in calves in France. Vet Parasitol 2000; 89(1-2): 1-9.

[8] Naciri M, Lefay MP, Mancassola R, Poirier P, Chermette R. Role of Cryptosporidium parvum as a pathogen in neonatal diarrhoea complex in suckling and dairy calves in France. Vet Parasitol 1999; 85(4): 245-57.

[9] O'Donoghue PJ. Cryptosporidium infections in man, animals, birds and fish. Aust Vet J 1985; 62(8): 253-8.

[10] O'Donoghue PJ. Cryptosporidium and cryptosporidiosis in man and animals. Int J Parasitol 1995; 25(2): 139-95.

[11] Fayer R. Cryptosporidium: a water-borne zoonotic parasite. Vet Parasitol 2004; 126: 37-56.

[12] O'Handley RM, Olson ME. Giardiasis and cryptosporidiosis in ruminants. Vet Clin North Am Food Anim Pract 2006; 22(3): 62343.

[13] Olson ME, O'Handley RM, Ralston BJ, McAllister TA, Thompson RC. Update on Cryptosporidium and Giardia infections in cattle. Trends Parasitol 2004; 20(4): 185-91.

[14] Bidewell CA, Cattell JH. Cryptosporidiosis in young alpacas. Vet Rec 1998; 142(11): 287.

[15] Waitt LH, Cebra CK, Firshman AM, McKenzie EC, Schlipf JW, Jr. Cryptosporidiosis in 20 alpaca crias. J Am Vet Med Assoc 2008; 233(2): 294-8.

[16] Whitehead C, Anderson DE. Neonatal diarrhea in llamas and alpacas. Small Rumin Res 2006; 61, 207-15.

[17] IVITA. Enfermedades infecciosas y parasitarias. Moro M, Ed. Diarrea atípica de las crías de alpaca. Boletin de divulgación de la Facultad de Medicina Veterinaria Lima, UNMSM-FMV-IVITA. $1965 ; 8,21-2$.

[18] Moro M. Enfermedades infecciosas de las alpacas y ovinos observadas en el Peru. Moro M, editor. Diarrea atípica de las crias de alpacas. Boletín de Divulgación de la Facultad de Medicina Veterinaria Lima, UNMSM-FMV-IVITA 1965; 4, 12-3.

[19] Cebra CK, Valentine BA, Schlipf JW, et al. Eimeria macusaniensis infection in 15 llamas and 34 alpacas. J Am Vet Med Assoc 2007; 230(1): 94-100.

[20] Palacios CA, Perales RA, Chavera AE, Lopez MT, Braga WU, Moro M. Eimeria macusaniensis and Eimeria ivitaensis coinfection in fatal cases of diarrhoea in young alpacas (Lama pacos) in Peru. Vet Rec 2006; 158(10): 344-5.

[21] Rosadio RH, Ameghino EF. Coccidial infections in neonatal Peruvian alpacas. Vet Rec 1994; 135(19): 459-60.

[22] Rojas M, Lobato Y, Montalvo M. Cryptosporidium en Camelidos Sudamericanos. Congreso Panamericano de Ciencias Veterinarias.Lima - Peru: Asociacion de Medicos Veterinarios; 1988; pp. $1-70$.

[23] Cebra CK, Mattson DE, Baker RJ, Sonn RJ, Dearing PL. Potential pathogens in feces from unweaned llamas and alpacas with diarrhea. J Am Vet Med Assoc 2003; 223(12): 1806-8.

[24] Starkey SR, Johnson AL, Ziegler PE, Mohammed HO. An outbreak of cryptosporidiosis among alpaca crias and their human caregivers. J Am Vet Med Assoc 2007; 231(10): 1562-7.
[25] Twomey DF, Barlow AM, Bell S, et al. Cryptosporidiosis in two alpaca (Lama pacos) holdings in the South-West of England. Vet J 2008; 175(3): 419-22.

[26] Waitt LH, Cebra CK, Firshman AM, McKenzie EC, Schlipf JW, Jr. Cryptosporidiosis in 20 alpaca crias. J Am Vet Med Assoc 2008; 233(2): 294-8.

[27] Lopez MT, Gonzalez AE, Rojo-Vazquez FA. Infección experimental de alpacas neonatas con Cryptosporidium parvum. Rev Acad Per Cienc Vet 2001; (2): 11-7.

[28] Proyecto de Cooperación Técnica en apoyo a la crianza y aprovechamiento de los Camélidos Sudamericanos en la Región Andina. Situación actual de los Camélidos Sudamericanos en Perú. FAO; 2005.

[29] Tzipori S, Angus KW, Gray EW, Campbell I, Allan F. Diarrhea in lambs experimentally infected with Cryptosporidium isolated from calves. Am J Vet Res 1981; 42(8): 1400-4.

[30] Tzipori S, Sherwood D, Angus KW, Campbell I, Gordon M. Diarrhea in lambs: experimental infections with enterotoxigenic Escherichia coli, rotavirus, and Cryptosporidium sp. Infect Immun 1981; 33(2): 401-6.

[31] Tzipori S, Angus KW, Campbell I, Gray EW. Experimental infection of lambs with Cryptosporidium isolated from a human patient with diarrhoea. Gut 1982; 23(1): 71-4

[32] Tzipori S. Cryptosporidiosis in animals and humans. Microbiol Rev 1983; 47(1): 84-96.

[33] Adesiyun AA, Kaminjolo JS, Ngeleka M, et al. A longitudinal study on enteropathogenic infections of livestock in Trinidad. Rev Soc Bras Med Trop 2001; 34(1): 29-35.

[34] Berriatua E, Green LE, Morgan KL. A descriptive epidemiological study of coccidiosis in early lambing housed flocks. Vet Parasitol 1994; 54(4): 337-51.

[35] Daugschies A, Najdrowski M. Eimeriosis in cattle: current understanding. J Vet Med B Infect Dis Vet Public Health 2005; 52(10): 417-27.

[36] Foreyt WJ. Epidemiology and control of coccidia in sheep. Vet Clin North Am Food Anim Pract 1986; 2(2): 383-8.

[37] Snoep JJ, Potters JB. Coccidiosis causes diarrhea in calves in the pasture. Pasture coccidiosis caused by Eimeria alabamensis. Tijdschr Diergeneeskd 2004; 129(5): 158-60.

[38] Henriksen SA, Pohlenz JF. Staining of cryptosporidia by a modified Ziehl-Neelsen technique. Acta Vet Scand 1981; 22(3-4): 5946.

[39] Gardner MJ, Altman DG. Estimating with confidence. Br Med J (Clin Res Ed) 1988; 296: 1210-1.

[40] Gardner MJ, Altman DG. Confidence--and clinical importance--in research findings. Br J Psychiatry 1990; 156: 472-4.

[41] Darabus G, Olariu R. The homologous and interspecies transmission of Cryptosporidium parvum and Cryptosporidium meleagridis. Pol J Vet Sci 2003; 6(3): 225-8.

[42] de Graaf G, Vanopdenbosch E, Ortega-Mora LM, Abbassi H, Peeters JE. A review of the importance of cryptosporidiosis in farm animals. Int J Parasitol 1999; 29(8): 1269-87.

[43] Moore DA, Zeman DH. Cryptosporidiosis in neonatal calves: 277 cases (1986-1987). J Am Vet Med Assoc 1991; 198(11): 1969-71.

[44] Garber LP, Salman MD, Hurd HS, Keefe T, Schlater JL. Potential risk factors for Cryptosporidium infection in dairy calves. J Am Vet Med Assoc 1994; 205(1): 86-91.

[45] Harp JA, Goff JP. Strategies for the control of Cryptosporidium parvum infection in calves. J Dairy Sci 1998; 81(1): 289-94.

[46] Trotz-Williams LA, Wayne MS, Leslie KE, Duffield T, Nydam DV, Peregrine AS. Calf-level risk factors for neonatal diarrhea and shedding of Cryptosporidium parvum in Ontario dairy calves. Prev Vet Med 2007; 82(1-2): 12-28.

[47] Trotz-Williams LA, Martin SW, Leslie KE, Duffield T, Nydam DV, Peregrine AS. Association between management practices and within-herd prevalence of Cryptosporidium parvum shedding on dairy farms in southern Ontario. Prev Vet Med 2008; 83(1): 11-23.

This is an open access article licensed under the terms of the Creative Commons Attribution Non-Commercial License (http://creativecommons.org/licenses/by-nc/3.0/) which permits unrestricted, non-commercial use, distribution and reproduction in any medium, provided the work is properly cited. 